\title{
Pengaruh Pemangkasan Reproduktif dengan Interval Bervariasi pada Komponen Hasil Dan Hasil Ubi Bengkuang (Pachyrhizus erosus L. Urban)
}

\author{
Efran Sitohang*, Sosiawan Nusifera dan Helmi Salim \\ Jurusan Agroekoteknologi Fakultas Pertanian, Universitas Jambi \\ Jl. Raya Jambi - Ma. Bulian KM. 15 Kampus Pinang Masak, Mendalo Darat, 36361 \\ Email: efransitohang54@gmail.com (*Penulis untuk korespondensi)
}

\begin{abstract}
ABSTRAK
Penelitian ini bertujuan mengetahui pengaruh pemangkasan reproduktif dengan interval bervariasi pada komponen hasil dan hasil ubi bengkuang. Percobaan dilaksanakan di Kebun Percobaan Fakultas Pertanian, Universitas Jambi, Mendalo Indah Kecamatan Jambi Luar Kota Kabupaten Muaro Jambi. Percobaan ini menggunakan Rancangan Acak Kelompok (RAK) yang terdiri dari satu faktor. Perlakuan yang diberikan terdiri atas 5 interval waktu peamngkasan reproduktif yaitu $P_{0}=$ Tanpa pemangkasan, $P_{1}=$ Pemangkasan dengan interval 3 hari, $\mathrm{P}_{2}=$ Pemangkasan dengan interval 6 hari, $\mathrm{P}_{3}=$ Pemangkasan dengan interval 9 hari dan $\mathrm{P}_{4}=$ Pemangkasan dengan interval 12 hari. Parameter yang diamati adalah jumlah ubi pertanaman, bobot ubi per tanaman, diameter ubi $(\mathrm{cm})$, panjang ubi $(\mathrm{cm})$, volume ubi $(\mathrm{ml})$, biomasa tanaman $(\mathrm{g})$, indeks panen $(\%)$ dan bobot ubi bengkuaang pertanaman (g). Data dianalisis dengan menggunakan analisis varians. Sebelumnya data diuji asumsi normalitasnya dengan mengunakan uji Kolmogorov-Smirnov. Selanjutnya, data yang telah teruji normal dianalisis dengan menggunakan Uji Duncan pada taraf alpa $5 \%$, Jika asumsi kenormalan data tidak terpenuhi maka dilakukan transformasi data sebelum melakukan analisis varians. Untuk mendapatkan interval pemangkasan yang optimum, dilakukan analisis regresi dengan menggunakan model regresi. Hasil menunjukkan bahwa terdapat pengaruh pemangkasan reproduktif dengan interval bervariasi pada komponen hasil dan hasil ubi bengkuang (Pachyrhizus erosus L. Urban) pada diameter ubi, panjang ubi, volume ubi, indeks panen ubi dan bobot ubi bengkuang per tanaman kecuali pada jumlah ubi pertanaman dan biomassa tanaman. Sedangkan interval pemangkasan yang optimum memberi komponen hasil dan hasil ubi bengkuang terbaik pada percobaan ini adalah dengan interval pemangkasan 7 hari dengan bobot ubi adalah $1.063,54 \mathrm{~g}$ per ubi.
\end{abstract}

Kata Kunci : Bengkuang, pemangkasan reproduktif, interval pemangkasan bervariasi, komponen hasil

\section{PENDAHULUAN}

Bengkuang adalah salah satu tanaman legum yang menghasilkan ubi akar yang sudah lama dikenal oleh masyarakat. Sejauh ini ubi bengkuang di Indonesia hanya dimanfaatkan sebagai bahan konsumsi segar padahal sebenarnya memiliki potensi industri yang cukup besar. 
Bengkuang (Pachyrhizus spp) umumnya berasal dari Meksiko dan Amerika Tengah (Vaughan and Geissler, 2009). Bengkuang (Pachyrhizus spp Rich. Ex DC) sebagaimana dikategorikan sebagai tanaman yang terabaikan dan belum termanfaatkan adalah salah satu tanaman legum neotropik yang menghasilkan ubi akar yang dapat dikonsumsi.

Tanaman bengkuang tidak banyak memerlukan air, sehingga cocok dibudidayakan di kebun atau tanah tadah hujan yang hanya mengandalkan air hujan. Penanaman yang tepat adalah pada awal musim hujan dengan harapan saat pertumbuhan vegetatif tanah dalam keadaan basah dan gembur. Dengan demikian penyerapan unsur hara berjalan sempurna, akhirnya dapat mempercepat perkembangan ubi. Meski tanaman bengkuang tidak banyak memerlukan air, tapi di wilayah Indonesia yang memang airnya terbatas, tanaman ini belum banyak dibudidayakan masyarakat. Tanaman bengkuang yang ditanam petani dibudidayakan secara kurang intensif, hanya sebagai tanaman sampingan atau tanaman sela sehingga produksinya semakin rendah. Padahal dengan cara pembudidayaan yang lebih intensif akan dapat menghasilkan produksi dan nilai ekonomis yang lebih tinggi. Usaha yang dapat di lakukan adalah pemangkasan dan pengaturan jarak tanam pada bengkuang (Dinas Pertanian Binjai, 2011).

Berdasarakan hasil analisis menyatakan $100 \mathrm{~g}$ ubi segar pada bengkuang dapat dilihat pada Tabel 1 .

Tabel 1. Komponen ubi bengkuang per 100 gram.

\begin{tabular}{ll}
\hline Komponen & Kandungan per 100 gram \\
\hline Air & $78 \%-94 \%$ \\
Pati & $2,1 \mathrm{~g}-10,7 \mathrm{~g}$ \\
Protein & $1 \mathrm{~g}-2,2 \mathrm{~g}$ \\
Lemak & $0,1 \mathrm{~g}-0,8 \mathrm{~g}$ \\
Vitamin C & $14 \mathrm{~g}-21 \mathrm{~g}$ \\
Karbohidrat & $10 \mathrm{~g}-22 \mathrm{~g}$ \\
Energi & $22 \mathrm{kal}-58 \mathrm{kal}$ \\
\hline
\end{tabular}

Sumber : Sorensen, 1996

Fakta ini mengindikasikan bahwa bengkuang sebenarnya merupakan sumber pati dan protein yang cukup potensial, oleh karena itu, industri tepung kaya protein berbasis bengkuang sangat memungkinkan untuk dikembangkan. Bengkuang dapat dikonsumsi dalam bentuk segar maupun sebagai campuran makanan yang lain seperti campuran sirup, tepung, maupun bahan baku industri kosmetika (Sørensen, 1996).

Salah satu teknik budidaya yang telah lama dikenal adalah pemangkasan (pruning). Pemangkasan dilakukan untuk berbagai tujuan seperti estetika, merangsang pembungaan, 
membentuk tajuk produktif, dan mengurangi daun-daun yang bersifat parasit fotosintat, yaitu daun yang ternaungi. Pemangkasan dilakukan untuk mengendalikan pertumbuhan. Dengan pemangkasan diharapkan arsitektur daun menjadi kompak dan jarak sumber (source) ke penyimpanan (sink) menjadi lebih pendek sehingga fotosintesis lebih efektif dan translokasi lebih cepat dan lancar (Ali, 1996). Selain itu pemangkasan dapat memperbaiki kuantitas hasil (Zulkarnain, 2010). Pada fase vegetatif, terjadi akumulasi pati pada bagian akar yang akhirnya akan membentuk ubi. Setelah tanaman memasuki fase reproduktif, asimilat akan ditarik ke sink reproduktif. oleh karena itu, pemangkasan sink reproduktif akan diasumsikan akan mengalihkan distribusi asimilat ke sink storage (ubi) (Karuniawan dan Nusifera, 2009).

Pendeknya interval potong menyebabkan pertumbuhan tanaman lambat dan kesempatan untuk tumbuh juga singkat, sedangkan pada pemotongan lebih lama kesempatan tumbuh lama sehingga tanaman dapat tumbuh optimal. Menurut Hobir (2002), kesempatan tumbuh yang lebih lama member kesempatan tanaman dapat menyerap hara lebih banyak sehingga dapat mencukupi untuk pertumbuhan tanaman. Hasil yang sama juga dilaporkan Mansur et. al. (2005), pada rumput Brachiaria humidicola yang interval potongnya lebih lama produksinya lebih tinggi seiring dengan pertumbuhan tanaman. Demikian juga Dasilveira et.al. (2010) rumput Panicum maximum intensitas pemotongan lebih sering maka panjang batang daun dan daun benderanya lebih panjang.

Semakin singkat interval pemangkasan mengakibatkan semakin singkat pula waktu yang dibutuhkan untuk mengumpulkan cadangan makanan dalam aktifitas pertumbuhan. Primandini (2007), menyatakan pemangkasan (defoliasi) berat mengakibatkan terhambatnya pembentukan tunas baru pada tanaman dan terkurasnya cadangan makanan tanaman.

\section{BAHAN DAN METODE}

Percobaan lapang dilakukan di kebun percobaan Fakultas Pertanian Universitas Jambi, Mendalo Darat, Kabupaten Muaro Jambi. Lahan percobaan yang digunakan terletak pada ketinggian 35 dpl dengan jenis tanah ultisols dengan $\mathrm{pH}$ tanah 4,62 - 4,9. Percobaan dilaksanakan selama 5 bulan dimulai pada bulan Oktober 2016 s.d. bulan Februari 2017. Bahan yang digunakan dalam percobaan meliputi benih bengkuang varietas lokal (kasang pudak), Urea, SP-36, dan KCl. Selain itu, dalam percobaan ini digunakan peralatan yang meliputi timbangan, jangka sorong, kamera, alat tulis dan berbagai alat bercocok tanam. 
Metode penelitian yang digunakan adalah metode percobaan yang disusun dalam Rancangan Acak Kelompok (RAK) yang terdiri atas 5 interval waktu pemangkasan reproduktif yang diulang 3 kali. Kelima taraf perlakuan tersebut adalah $\mathrm{P}_{0}$ : tanpa pemangkasan reproduktif, $\mathrm{P}_{1}$ : pemangkasan dengan interval 3 hari, $\mathrm{P}_{2} \quad$ : pemangkasan dengan interval 6 hari, $\mathrm{P}_{3}$ : pemangkasan dengan interval 9 hari dan $\mathrm{P}_{4}$ : pemangkasan dengan interval 12 hari. Variabel parameter yang diamati adalah jumlah ubi pertanaman, bobot ubi per tanaman, diameter ubi $(\mathrm{cm})$, panjang ubi $(\mathrm{cm})$, volume ubi $(\mathrm{ml})$, biomasa tanaman (g), indeks panen (\%) dan bobot ubi bengkuaang pertanaman $(\mathrm{g})$. Data dianalisis dengan menggunakan analisis varians. Sebelumnya data diuji asumsi normalitasnya dengan mengunakan uji Kolmogorov-Smirnov. Selanjutnya, data yang telah teruji normal dianalisis dengan menggunakan Uji Duncan pada taraf alpa 5\%, Jika asumsi kenormalan data tidak terpenuhi maka dilakukan transformasi data sebelum melakukan analisis varians. Untuk mendapatkan interval pemangkasan yang optimum, dilakukan analisis regresi dengan menggunakan model regresi.

\section{HASIL DAN PEMBAHASAN}

\section{Kondisi Umum Lingkungan Percobaan}

Percobaan lapangan dilakukan pada lingkungan yang kondisi lahannya sesuai untuk syarat tumbuh tanaman bengkuang. Untuk membuat kondisi tanah menjadi lembab untuk proses perkecambahan dilakukan penyiraman 2 kali sehari yaitu pagi dan sore hari. Kurangnya ketersediaan air tanah berdampak bagi pertumbuhan tanaman sehingga pertumbuhan tanaman kurang optimal. Sebaliknya, jika ketersediaan air tanah cukup bagi tanaman, terlihat pertumbuhan tanaman jauh lebih baik. Hal ini terlihat dari pertumbuhan tanaman yang sangat subur.

Selama percobaan berlangsung terdapat beberapa hama yang menyerang tanaman bengkuang antara lain, babi hutan (Sus scrofa domesticus) yang mengakibatkan rusaknya beberapa plot percobaan. Hama lainnya adalah walang sangit (Leptocorisa acuta), belalang (Valanga nigricornisy), kumbang kubah (Epilachna sparsa) yang menyebabkan kerusakan pada daun. Tanaman yang terserang umumnya tanaman yang berada di pinggir plot-plot percobaan.

Penyakit yang menyerang pada tanaman bengkuang adalah penyakit bercak daun yang mengakibatkan pada daun terlihat bercak-bercak dan penyakit layu bakteri yang mengakibatkan pada pangkal batang pada tanaman ini menjadi layu dan lama-kelamaan 
menjadi kering. Gulma yang tumbuh di areal plot-plot percobaan adalah alang-alang (Imperata cylindrica), rumput teki (Cyperus rotundus), putri malu (Mimosa pudica), kakawatan (Cynodon dactylon) dan rumput paitan (Axonophus compresus). Pengendalian gulma dilakukan dengan cara manual yaitu dengan penyiangan. Penyiangan gulma ini dilakukan selama dua minggu sekali.

Dalam teknik budidaya tanaman bengkuang (Pachyrrhizus erosus L. Urban) untuk meningkatkan potensi kualitas hasil dan hasil ubi bengkuang dengan melakukan salah satu teknik budidaya yang dikenal yaitu pemangkasan reproduktif (reproductive pruning). Pengaplikasian pemangkasan ini dilakukan pada saat tanaman berumur 2 bulan (saat $50 \%$ tanaman telah memasuki fase berbunga).

\section{Hasil}

\section{Jumlah Ubi Per Tanaman}

Hasil analisis ragam memperlihatkan bahwa tidak terdapat pengaruh pemangkasan reproduktif dengan interval bervariasi yaitu pada jumlah ubi per tanaman. Rata-rata jumlah ubi pertanaman pada percobaan ini adalah satu buah ubi pertanaman.

\section{Diameter Ubi}

Hasil analisis ragam memperlihatkan bahwa terdapat pengaruh pemangkasan reproduktif dengan interval bervariasi pada diameter ubi. Rata-rata diameter ubi pertanaman terdapat pada tabel 2.

Tabel 2. Diameter ubi yang diberi perlakuan pemangkasan dengan interval bervariasi.

\begin{tabular}{lll}
\hline Perlakuan & Diameter Ubi $(\mathrm{mm})$ & \\
\hline Tanpa pemangkasan & 53.98 & $\mathrm{~b}$ \\
Interval 3 hari & 118.8 & $\mathrm{a}$ \\
Interval 6 hari & 124.86 & $\mathrm{a}$ \\
Interval 9 hari & 107.75 & $\mathrm{a}$ \\
Interval 12 hari & 114.4 & $\mathrm{a}$ \\
\hline
\end{tabular}

Keterangan: Angka-angka yang diikuti dengan huruf-huruf yang tidak sama menunjukkan berbeda nyata menurut Uji Duncan pada taraf $\alpha$ 5\%.

Perlakuan pemangkasan berpengaruh pada diameter ubi. Namun demikian variasi interval pemangkasan tidak menunjukkan pengaruh. Berdasarkan Tabel 2, pemangkasan dengan interval 12 hari telah mampu meningkatkan diameter ubi bengkuang, sedangkan peningkatan frekuensi pemangkasan tidak lagi dapat meningkatkan diameter ubi. 


\section{Panjang Ubi}

Hasil analisis ragam memperlihatkan bahwa terdapat pengaruh pemangkasan reproduktif dengan interval bervariasi pada panjang ubi. Rata-rata panjang ubi pertanaman terdapat pada tabel 3 .

Tabel 3. Panjang ubi yang diberi perlakuan pemangkasan dengan interval bervariasi.

\begin{tabular}{llc}
\hline Perlakuan & Panjang Ubi $(\mathrm{cm})$ & \\
\hline Tanpa pemangkasan & 11.1 & $\mathrm{c}$ \\
Inteerval 3 hari & 15.8 & $\mathrm{ab}$ \\
Interval 6 hari & 16.33 & $\mathrm{ab}$ \\
Interval 9 hari & 16.76 & $\mathrm{a}$ \\
Interval 12 hari & 15.11 & $\mathrm{~b}$ \\
\hline
\end{tabular}

Keterangan : Angka-angka yang diikuti dengan huruf-huruf yang tidak sama menunjukkan berbeda nyata menurut Uji Duncan pada taraf $\alpha$ 5\%.

Perlakuan pemangkasan berpengaruh pada panjang ubi. Namun demikian variasi interval pemangkasan tidak menunjukkan pengaruh. Berdasarkan Tabel 3, pemangkasan dengan interval 12 hari telah mampu meningkatkan panjang ubi bengkuang, sedangkan peningkatan frekuensi pemangkasan tidak lagi dapat meningkatkan panjang ubi.

\section{Volume Ubi}

Hasil analisis ragam memperlihatkan bahwa terdapat pengaruh pemangkasan reproduktif dengan interval bervariasi pada volume ubi. Rata-rata volume ubi pertanaman terdapat pada tabel 4.

Tabel 4. Volume ubi yang diberi perlakuan pemangkasan dengan interval bervariasi.

\begin{tabular}{lll}
\hline Perlakuan & Volume Ubi $(\mathrm{ml})$ & \\
\hline Tanpa pemangkasan & 104.26 & $\mathrm{~b}$ \\
Interval 3 hari & 808.9 & $\mathrm{a}$ \\
Interval 6 hari & 817.61 & $\mathrm{a}$ \\
Interval 9 hari & 657.8 & $\mathrm{a}$ \\
Interval 12 hari & 709.03 & $\mathrm{a}$ \\
\hline
\end{tabular}

Keterangan : Angka-angka yang diikuti dengan huruf-huruf yang tidak sama menunjukkan berbeda nyata menurut Uji Duncan pada taraf $\alpha 5 \%$.

Perlakuan pemangkasan berpengaruh pada volume ubi. Namun demikian variasi interval pemangkasan tidak menunjukkan perbedaan volume ubi. Berdasarkan Tabel 4, pemangkasan dengan interval 12 hari telah mampu meningkatkan volume ubi bengkuang, sedangkan peningkatan frekuensi pemangkasan tidak lagi dapat meningkatkan volume ubi. 


\section{Biomassa Tanaman}

Hasil analisis ragam memperlihatkan bahwa bahwa tidak terdapat pengaruh pemangkasan reproduktif dengan interval bervariasi pada biomassa tanaman. Rata-rata biomassa tanaman pada percobaan ini adalah $144.06 \mathrm{~g}$.

\section{Indeks Panen Ubi}

Hasil analisis ragam memperlihatkan bahwa terdapat pengaruh pemangkasan reproduktif dengan interval bervariasi pada indeks panen ubi. Rata-rata indeks panen terdapat pada tabel 5 .

Tabel 5. Indeks panen ubi yang diberi perlakuan pemangkasan dengan interval bervariasi.

\begin{tabular}{lcc}
\hline Pemangkasan & Indeks Panen $(\%)$ & \\
\hline Tanpa pemangkasan & 7.06 & $\mathrm{~b}$ \\
Interval 3 hari & 46.74 & $\mathrm{a}$ \\
Interval 6 hari & 43.34 & $\mathrm{a}$ \\
Interval 9 hari & 47.11 & $\mathrm{a}$ \\
Interval 12 hari & 43.81 & $\mathrm{a}$ \\
\hline
\end{tabular}

Keterangan : Angka-angka yang diikuti dengan huruf-huruf yang tidak sama menunjukkan berbeda nyata menurut Uji Duncan pada taraf $\alpha 5 \%$.

Perlakuan pemangkasan berpengaruh pada indeks panen ubi. Namun demikian variasi interval pemangkasan tidak menunjukkan pengaruh. Berdasarkan Tabel 5, pemangkasan dengan interval 12 hari telah mampu meningkatkan indeks panen ubi bengkuang, sedangkan peningkatan frekuensi pemangkasan tidak lagi dapat meningkatkan indeks panen ubi.

\section{Bobot Ubi Per Tanaman}

Hasil analisis ragam memperlihatkan bahwa terdapat pengaruh pemangkasan reproduktif dengan interval bervariasi pada diameter ubi. Rata-rata bobot ubi per tanaman terdapat pada tabel 6.

Perlakuan pemangkasan berpengaruh pada bobot ubi per tanaman. Namun demikian variasi interval pemangkasan tidak menunjukkan pengaruh. Berdasarkan Tabel 6, pemangkasan dengan interval 12 hari telah mampu meningkatkan bobot ubi per tanaman bengkuang, sedangkan peningkatan frekuensi pemangkasan tidak lagi dapat meningkatkan bobot ubi per tanaman. 
Tabel 6. Bobot ubi per tanaman yang diberi perlakuan pemangkasan dengan interval bervariasi.

\begin{tabular}{llc}
\hline Pemangkasan & \multicolumn{2}{l}{ Bobot Ubi Per Tanaman $(\mathrm{g})$} \\
\hline Tanpa pemangkasan & 153.33 & $\mathrm{~b}$ \\
Interval 3 hari & 1039.5 & $\mathrm{a}$ \\
Interval 6 hari & 1034.83 & $\mathrm{a}$ \\
Interval 9 hari & 772.16 & $\mathrm{a}$ \\
Interval 12 hari & 909.83 & $\mathrm{a}$ \\
\hline
\end{tabular}

Keterangan: Angka-angka yang diikuti dengan huruf-huruf yang tidak sama menunjukkan berbeda nyata menurut Uji Duncan pada taraf a 5\%.

Interval pemangkasan optimum pada bobot ubi diperoleh dengan cara analisis regresi pada lampiran 11, Berdasarkan analisis regresi hubungan antara interval pemangkasan dengan bobot ubi dapat dijelaskan melalui model persamaan :

$$
y=-13,93 x^{2}+208,67 x+282,086
$$

Titik optimum atau interval optimum diperoleh dengan melakukan diferensial terhadap persamaan tersebut sehingga diperoleh interval 7,49 hari dengan hasil maksimal $1.063,546 \mathrm{~g}$.

\section{Pembahasan}

Pada jumlah ubi pertanaman dapat dilihat bahwa pemberian perlakuan pemangkasan reproduktif dengan interval waktu tidak ada pemangkasan, 3 hari, 6 hari, 9 hari dan 12 hari menghasilkan nilai rata-rata adalah satu ubi per tanaman. Secara umum, terdapat dua jenis ubi berdasarkan jumlahnya yaitu ubi tunggal (mono tuber) dan ubi ganda (multi tuber) (Sorensen, 1996). Sorensen (1996) mengatakan adanya kendali genetik pada karakter ini untuk menentukan terbentuk atau tidaknya karakter ubi ganda pada bengkuang.

Secara umum bobot ubi berhubungan dengan panjang ubi, volume ubi dan diameter ubi. Pada hasil pengamatan bobot ubi, volume ubi, panjang ubi dan diameter ubi hal ini sesuai dengan pendapat Nusifera (2007) yang menyatakan fakta ini mengindikasikan bahwa penambahan volume diikuti dengan penambahan panjang dan diameter ubi tanpa mengubah bentuk dasar ubi, namun terlihat ada variasi penambahan diameter ubi sehingga penambahan volume pun bervariasi. Terjadinya peningkatan pada volume ubi, panjang ubi dan diameter ubi bengkuang diduga karena adanya pengaruh pemangkasan sehingga pengaruh pemangkasan bekerja baik. Pengaruh dari pemangkasan reproduktif ini diharapkan arsitektur tanaman menjadi kompak dan jarak sumber (source) ke penyimpanan (sink) menjadi lebih pendek sehingga fotosintesis lebih efektif dan translokasi lebih cepat 
dan lancar (Ali,1996). Pemangkasan ini mengakibatkan meningkatnya aliran asimilat ke bagian ubi yang berakibat pada berubahnya ukuran ubi. Peningkatan ukuran ubi selayaknya akan mengalami penyelarasan dengan bentuk dasar ubi. Cukupnya ketersediaan air tanah sangat menentukan perubahan dan penampilan ubi bengkuang. Efisiensi tanaman dalam memproduksi asimilat meningkat jika kebutuhan air cukup (Taiz dan Zeiger, 1998). Pemangkasan akan memperbesar peluang sink lainnya untuk mendapatkan asimilat dalam jumlah yang lebih banyak terutama bila yang dibuang adalah sink-sink kuat seperti sink reproduktif. Selain itu, pemangkasan bunga dapat meningkatkan adaptasi tanaman pada kondisi kekeringan (Diouf et al., 1998). Beberapa peneliti telah melaporkan adanya pengaruh pemangkasan terhadap peningkatan hasil ubi bengkuang.

Variabel biomasa tanaman dan indeks panen pada dasarnya bertujuan mempelajari sejauh mana akumulasi fotosintat dan bagaimana tingkat partisi fotosintat ke bagian yang bernilai ekonomis yaitu ubi. Biomasa tanaman merupakan total bahan kering seluruh organ tanaman (Sitompul dan Guritno, 1991) termasuk bahan kering ubi sedangkan indeks panen adalah proporsi bahan kering organ yang dipanen dengan total bahan kering tanaman. Terlihat bahwa pertumbuhan pupus yang sangat subur sedangkan asimilat yang didistribusikan ke bagian ubi cenderung lebih sedikit sehingga ukuran ubi relatif lebih kecil. Perlakuan pemangkasan sebagaimana yang telah dilaporakan oleh Nielsen et al. (1999) dan Sorensen (1996) mampu meningkatkan bobot ubi secara signifikan. Nusifera (2007) menyatakan bahwa variasi bobot kering pupus adalah faktor penentu nilai rasio bobot ubi dan biomasa tanaman. Jika bobot kering pupus cenderung tinggi dengan asumsi bobot ubi tetap, maka tentunya nilai indeks panen akan semakin kecil, Sebaliknya. Biomassa tanaman dan indeks panen dengan bobot ubi tanaman memberikan peningkatan dikarenakan hasil fotosintat ditranslokasi ke penyimpanan (storage) dan meningkatkan bobot ubi. Mekanisme pemangkasan dalam meningkatkan bobot ubi adalah dengan mengubah pola partisi fotosintat (karbon) antara sink-sink alternatif. Melalui pemangkasan sink reproduktif, asimilat akan diarahkan ke sink storage (ubi) dengan demikian indeks panen akan meningkat.

Berdasarkan hasil analisis regresi pada lampiran 11, interval pemangkasan yang optimum untuk memperoleh bobot ubi tertinggi pada percobaan ini adalah dengan interval pemangkasan 7 hari dengan bobot ubi adalah 1.063,546 g per ubi. Hal ini diduga karena interval pemangkasan yang lebih pendek menyebabkan pengurangan cadangan makanan akibat pemangkasan yang lebih intensif, sehingga tanaman hanya memiliki waku singkat untuk membentuk cadangan makanan. Hal ini seusai dengan pendapat Primandini (2007), 
yang menyatakan bahwa pemangkasan mengakibatkan terhambatnya pembentukan tunas baru dan terkurasnya cadangan makanan. Sebaliknya dengan interval pemangkasan yang lebih panjang menyebabkan cadangan makanan lebih banyak untuk ditranslokasikan ke storage (ubi),sehingga tanaman memiliki waktu yang panjang untuk membentuk cadangan makanan. Hal ini sesuai dengan pendapat Rahman (2002) biasanya dengan memperpanjang interval pemangkasan agar tanaman memperoleh kesempatan yang lebih lama untuk mengembangkan perakarannya serta mengakumulasikan fotosintat ke dalam sistem jaringan meristem akar dan tajuk tanaman.

\section{KESIMPULAN DAN SARAN}

Berdasarkan hasil penelitian tentang pengaruh pemangkasan reproduktif dengan interval bervariasi pada komponen hasil dan hasil ubi bengkuang (Pachyrhizus erosus L. Urban) dapat disimpulkan bahwa pemangkasan dengan interval bervariasi berpengaruh pada diameter ubi, panjang ubi, volume ubi, indeks panen ubi dan bobot ubi bengkuang per tanaman kecuali pada jumlah ubi pertanaman dan biomassa tanaman. Sedangkan interval pemangkasan yang optimum memberi komponen hasil dan hasil ubi bengkuang terbaik pada percobaan ini adalah dengan interval pemangkasan 7 hari dengan bobot ubi adalah $1.063,54 \mathrm{~g}$ per ubi.

\section{DAFTAR PUSTAKA}

Ali, A. I. 1996. Pengaruh Waktu Pemangkasan Tajuk dan Populasi Tanaman Terhadap Hasil Empat Klon Ubi Jalar (lpomoea batatas Lam.). skripsi. IPB, Bogor.

Dasilveira, M.C.T., D. Nascimento Junior, B.A.I. Dacunta, G.S. Difante, K.S. Pena, S.C. Daliva and A.F. Sbrissia. 2010. Effect of cutting interval and cutting height on morphogenesis and forage accumulation of guinea grass (Panicum maximum). Trop. Grassl. 44: 103-108.

Dinas Pertanian Binjai, 2011. Kota Binjai.

Diouf, O.,M. H. Roy-McCauley, and D.J.M. Anne Rose. (1998). Tuber-pod competition and drought responses in Yam Bean (Pachyrhizus ahipa (Wedd.) Parodi). In: Sørensen, M., J.E. Estrella, O.J. Hamann and S.A. Rios Ruiz (eds.), Proceedings of the 2nd international symposium on tuberous legumes, Celaya, Guanajuato, Mexico 5-8 August 1996, pp. 407-412. Copenhagen, Denmark.

Hobir. 2002. Pengaruh selang panen terhadap pertumbuhan dan produksi Nilam. J. Littri. 8: 103-107. 
Karuniawan, A dan S. Nusifera. 2009. Respon Tanaman bengkuang terhadap pemangkasan reproduktif untuk karakter hasil dan kualitas ubi. Skripsi Fakultas Pertanian Universitas Pajajaran, Bandung.

Mansur, H. Djuned, T. Dhalika, S. Hardjosoewignyo dan L. Abdullah. 2005. Pengaruh interval pemotongan dan invasi gula Chromolaena odorata terhadap produksi dan kualitas rumput Brachiaria humidicola. Media Petern. 28: 77-86.

Nielsen, P.E., M. Halafihi, and M. Sørensen. 1999. Pruning practices in Pachyrhizus tuberosus (Lam.) Spreng. Trop. Agric. (Trinidad) Vol. 76 No. 4 October 1999.

Nusifera S., 2007. Respons Tanaman Bengkuang Budidaya (Pachyrrhizus Erosus L. Urban) Terhadap Pemangkasan Reproduktif Untuk Karakter Hasil Dan Kualitas Ubi.

Primandini, Y. 2007. Fooder. (online) (yuniee07@ yahoo.co.id).

Rahman, S., 2002. Penerapan Pertanian Organik. Kanisius, Yogyakarta.

Sitompul, S. M. dan B. Guritno, 1995. Analisis Pertumbuhan Tanaman. Gadjah Mada University Press, Yogyakarta.

Sørensen, M. 1996. Promoting The Conservation and Use of Neglected Crops 2: Yam Bean Pachyrhizus DC. International Plant Genetic Resources Institute, Italy.Sørensen, M., D.F. Adjahossou, D.J.

Taiz, L and Zeinger, E., 1998. Plant Physiology. Sinauer Assocites, Inc, Publishers Sunderland, Massachusetts.

Vaughan, J. G. and Geissler, C. A. 2009. The New Oxford Book of Food Plants. Oxford University Press Inc, New York.

Zulkarnain, 2010. Dasar - Dasar Hortikultura. PT. Bumi Aksara. Jakarta. 